\title{
A New Approach to Manage Welding Quality in Supply Chain Networks: A Supplier Network Complaints Perspective
}

\author{
Jenni Toivanen ${ }^{1}$, Harri Eskelinen ${ }^{2}$, Paul Kah ${ }^{1}$, Jukka Martikainen ${ }^{1}$, Pia Heilmann ${ }^{3}$ \\ ${ }^{1}$ School of Energy Systems (Welding Technology), Lappeenranta University of Technology, Lappeenranta, Finland \\ ${ }^{2}$ School of Energy Systems (Manufacturing Technology), Lappeenranta University of Technology, Lappeenranta, Finland \\ ${ }^{3}$ School of Business and Management, Lappeenranta University of Technology, Lappeenranta, Finland
}

Email address:

jenni.toivanen@lut.fi (J. Toivanen)

\section{To cite this article:}

Jenni Toivanen, Harri Eskelinen, Paul Kah, Jukka Martikainen, Pia Heilmann. A New Approach to Manage Welding Quality in Supply Chain Networks: A Supplier Network Complaints Perspective. International Journal of Mechanical Engineering and Applications.

Vol. 5, No. 2, 2017, pp. 95-106. doi: 10.11648/j.ijmea.20170502.14

Received: February 21, 2017; Accepted: March 3, 2017; Published: March 28, 2017

\begin{abstract}
This study presents a five-step method for analysis of supply chain networks from the perspective of the welding quality of manufactured products. The presented approach gives tools to take care of welding quality assessment in supply chain networks. The study uses data based analysis of complaints data and survey results to provide information that may assist managerial decision-making and supplier-related marketing activities. The results reflect the importance of information sharing as a means to reduce the number of complaints and show that combining production data and information about the production offers potential for manufacturing quality development in the supply chain network. The study uses applied RACI matrix and the case of a welding supply chain network to establish the findings. The case example discusses the observations dealing with GMAW process.
\end{abstract}

Keywords: Complaint Management, RACI Matrix, Supplier Quality, Supply Chain Network, Welding Quality Assessment

\section{Introduction}

As theories and doctrines of business process management change and develop to reflect changing business and societal contexts, manufacturing networks have been receiving progressively more attention. Networks are evolving relationships and embody multiple interconnections between network members [1] and, thus, business networks with suppliers are generally accepted as being complex environments [2]-[4]. Study of business networks has encompassed many different perspectives, for instance, network cooperation [1], network competencies [5], network learning [6], network strategy [7] and network management [1], [8], and many different concepts, e.g. network dimensions [8], network insights [9] and network dynamics [10], [11]. Recent research has tried to improve understanding of business networks through the use of network pictures [12], [13], which are different understandings of how business network actors subjectively comprehend their surroundings [13]. The approach has been considered from a number of different viewpoints, e.g. network pictures complexity [2], relationships to suppliers [14], supplier management [15], [16] and making pictures as organizational sense making [17]. Additionally, researchers have shown growing interest in stepping beyond the concrete to find understanding of sensing of business activities in operational actions rather than building forecasts of its entity [17], [18].

The extent of network studies is considerable and the topic has been considered from many different viewpoints. Manufacturing networks have been studied by many scholars, who have considered the issue from different perspectives of the supply chain. General reviews of network activity such as Wilhelm [1], Rudberg and Olhager [19] and Chang et al. [20] and study of quality management in the supply chain [21], while providing valuable information, do not specifically address complaint management and its role as a driver for improved production. Use of complaint data 
from a network perspective is a new approach to investigation of quality, efficiency, productivity and profitability in industrial networks and manufacturing.

In light of notions that networks encompass multiple viewpoints and contexts with dynamic relationships and activity [22], manufacturing networks can be seen as consisting of several supply chain strings [1] and supply networks [23], which can be sets of supply chains [24], and the supply chain can thus have different supply network structures [25]. This research focuses on the supplier network [26], [27] structure in a supply chain network [20].

Quality is an important collaborative advantage in network structures [28] and is presumed to provide competitive advantage [29]. This study aims to conceptualize a method to observe the quality of manufacturing by analysing the structure and interrelationships of complaints in a supply chain network. This information can help companies to concretize the picture of discrepancies in the supply chain network and thus create a basis for development targets and network marketing activities that promote profitability. Different types of optimizing approaches have been tried to handle the cases of a product change which allow the efficient production and a wide product variety [30]. The complaint data discussed in this research includes also observations, which are connected with different types of product changes.

This study uses the case of a welding supplier network exhibiting features specific to manufacturing. The case study is used to observe manufacturing supply chain network related phenomena on the basis of data collected from industry. The collected data deals with the observations of gas metal arc welding (GMAW) process. This work may help managers reflect on the importance of production data and sense of surroundings as tools to improve strategic performance and network behaviour. The study empirically investigates the impact of cooperation and knowledge transfer in a dynamic supply chain network. More specifically, the study considers the relation of deficient knowledge transfer regarding defects in welding manufacturing in the light of welding complaints in the supplier network. The results indicate that improved cooperation can decrease the number of complaints and promote enhanced network behaviour among network members. Conversely, deficiencies in cooperation and knowledge transfer can be observed in the nature of the complaints in the manufacturing network. The presented five-step method can help certain development targets in the light of manufacturing quality in the supplier network. The systematic way to recognize and analyse possible product and production failures [31] makes it possible to carry out improvements and increase the productivity in welding production.

The study explores the following research questions: how can a processing model of complaint data be created that recognizes development targets in the supply chain network using existent, recent data? How can development targets be directly identified with information about welding quality and production complaints? What are the benefits of the prospective analytical model and how the model supports welding quality assessment when a substantial volume of complaint data is to be analysed?

The paper is divided into a theoretical part and a practical research part. First, the paper reviews existing information on networks and supply chain networks that is related to quality of manufacturing and cooperation. Next, the research section describes the steps of the proposed five-step method comprising collection and categorization of the complaints data and its integration with observations and impressions of the supplier network. The paper examines the case supply chain network and explains the relation between existing information on quality and defects and the assumption of a need to increase cooperation and information sharing. Finally, the paper presents a new method for using complaint data to develop a quality, productive and profitable outcome. The paper presents conclusions based on analysis of the results and discussion of the research questions and concludes with proposals for further studies.

\section{Perspectives of Networking}

To form an overall picture of the network environment under study, literature-based background information is presented dealing with the management of network structures in general and the special features of supply chain networks in particular.

\subsection{Features of Business Networks}

Networks exhibit considerable complexity [1]-[3] and they are a business environment that poses challenges for optimal functioning of firms with manufacturing entities. Networks consist of multiple relationships [6] and relationships are one of the most important factors to observe when studying network behaviour. The relationships with and between suppliers, in particular, have become a topic of interest for strategic development of the focal company's business [15]. It is evident that business networks are dynamic and their management as part of manufacturing chains imposes additional demands.

Today's business processes drive companies to cooperate and extend dyadic relationships [32]. Companies cannot be seen in isolation but need to be considered within the wider context of business [4] and companies are thus involved in a complex network environment with internal relationships [4] and a context of multiple actors [8]. At the same time, companies have to respond to the challenges of globalization of business strategies and demands for sustainability of supply chains [33]. Managing network relationships demands knowledge of the interconnections involved [16]. However, when managing network relationships, there can be a mismatch between the actors that a company sees as relevant and those with whom they interact [4].

The multiple actors involved and the dynamic nature of networks mean that networks have features of business activity with non-predictable outcomes [11] and they cannot 
be directed or controlled by a single company [11], [34]. Network activities are the result of the network structure, networking behaviour and network outcomes [8]. When investigating the directions of network behaviour, the horizontal direction is more complex than the vertical direction [1] but all directions of relationships with network members are important.

Even if networks cannot be viewed as a function of a single company and a single company perspective gives an incomplete view of the business context and may be considered an inadequate basis for understanding of network dynamics [8], such an approach to observing networks is not without merit [17] and can help to understand steps in the development of different functions and the business network. Investigation of the dynamics of a network promotes recognition of significant changes in network actions or rather diminishes the role of unrecognized changes [15]. To study a network's behaviour or develop actions in a network, division of the network into constituent parts can be implemented to reveal detailed information. The network can be divided into sub-networks such as the logistics and distribution network [35], [36], production network [4], supply chain network [3], [20], [37], [38] or supplier network [15].

Managing network structures is complex and demanding [18] and researchers are searching for information that may enable a strategic tool to be developed that can enhance business advantage. Multiple network business models have thus been developed for analysis of network environments. Relationships are the result of strategic decisions and concomitant actions [39], and reflect the impact of management of the network structure. Thus, existing relationships can restrain the adoption of new ways of operating and managing business activities [39]. Researchers are trying to enhance transparency in network activities in efforts to develop network management strategies [18]. Clarity regarding operational activities between a focal company and suppliers can enhance strategic decisionmaking in the supply chain network [40], and appropriate forms of cooperation and network management can have a positive impact on the development of product quality and profitability in production.

\subsection{Special Features of Supply Chain Network}

In a network, the connections are built with linkages that present via inter-firm transactions, interactions and ongoing relationships in the vertical direction or horizontal direction [41]. The extent of a supply chain network is determined by the number of linkages and the energy of activities by the intensity of cooperation. Supply chain networks contain multiple supply chains and actors connected with each other in a unique context [20]. Suppliers, manufacturers, distributors and retailers are connected through product, material, information and financial flows [3].

The upstream, downstream or collaborative connections and their linkages are directly related to cooperation flows. Continuous and unhindered cooperation and information transfer can be difficult to achieve even when the advantages that the network activity can bring are recognized. Information sharing and cooperation and relationships management can generate managerial advantage and improve performance [5], [36]. Knowledge transfer plays a central role in the development of dynamic models within the network and augmentation of competitive advantage gained from the network [42]. Generally, intra-firm knowledge transfer is considered easier than knowledge transfer between firms [43].

It is important to recognize the objectives that are want to be achieved with knowledge in the network [42]. Knowledge transfer and supply chain network advantages are related to competencies [5] and the capability of an individual or firm level to attain specific achievements [44]. Thus, tacit knowledge and experience of individuals, firms or network levels introduce complexity into network management because of changing configurations of cooperation [43]. In a supply chain network, manufacturing activity management and cooperation should include appropriate knowledge transfer between the entities involved. Management practices related to quality improvement and operational efficiency should also be included in information sharing for effective network behaviour [5].

Improved quality is one of the advantages of supply chain network collaboration [28] and value-adding processes [37] in which the focal company defines the product quality [45]. Consequently, the value of relationships in the supply chain network gain in importance. Cooperation and divided management with customer and supplier can bring increasing performance and competitive advance on manufacturing [46]. Deficits in cooperation can result higher defect rates in manufacturing. One actor in a supply chain network can cause quality failure in the end product [47]. Viewing product quality discrepancies from the perspective of incompetent cooperation [47] can reveal deficiencies in relationships and knowledge transfer. Supply chain networks are vulnerable to risks of financial uncertainty [3] but also have properties that can offer a sustained competitive advantage [20].

However, discrepancies in quality are common in production [48] and defects leading to complaints are almost inevitable in production involving a supply chain network context [49]. Managing complaints and complaint behaviour are notable factors in business relationships [50] and measuring of manufacturing performance [51]. In a supply chain network context, analysis of complaints can indicate targets for development. To maintain competitive advantage in manufacturing, continuous product quality improvement is essential and the effective use of quality data (e.g. complaint data) is a critical factor in business development [52]. The literature review has shown that network context analysis is a powerful tool to evaluate the influence of complaints on product and production.

\section{Research Basis and Methods}

To carry out successful supply chain network analysis, the 
key nodes of the network, the different types of connections between them and the volume of conveyed information first have to be identified (see e.g. [53], [54]). In this research, the focus is on determining the information content in the network context when the structure of the network and its actors are identified. In this study, the research methodology used for supply chain network analysis and development is based on three combined research methods. The research utilizes a case research method [55], which is a typical approach in network studies [56]. The case method is used to build a basis for a new method to develop supply chain network quality and improved performance with profitable outcomes. The resulting data are analysed with a mixed method approach [57] based on a number of different data collection and analysis methods [58]. The data collection and analysis utilize a quantitative analysis approach [59] and the data are analysed using qualitative content analysis [60]. The data for analysis consist of numerical data of complaints, empirical analysis results and a survey of the supplier network.

This study investigates the case industry network using existent numerical data about complaints concerning welded items manufactured in the supplier network. The study utilizes information about complaints $(n=18$ 889) to clarify the prospects of improving network quality and profitability in the supplier network. The data are related to the end product with multiple items $(\mathrm{n}=14$ 907) and additionally utilize a survey of suppliers $(\mathrm{n}=10)$. The case end products that are used to concretize the data are two different mobile machines for applications in demanding environments and thus represent an example of a multi-level manufacturing process with multiple actors in the supply chain network. The combined complaint data and survey results are analysed using a data matrix and the RACI matrix, which is an approach commonly used for study of business processes [61], [62] and organizational management [63].

\section{Study}

To create a generalized method for establishing targets of development, a case of industrial production demonstrating the special features of welding technology is used. Toivanen et al. [64] studied the welding network and concluded that there was insufficient network behaviour. The lack of communication internally and at the network level can form of defects and complaints in the supply chain network. The lack of communication both restrains network development and decreases profitability in the network. On the basis of this prior assumption, a method is required for finding development targets. The method aims to find a way to integrate data of complaints and survey with relevant complaint information collected from suppliers without filtering out any important information to be analysed. The method should ensure that reliable production development targets can be found.

\subsection{Classification of the State of Complaints}

The first step of the process using complaints in a supply chain network was to create an overview of the type of complaints and thus the targets of development. In this step, the case supply chain network was studied with focus on the supplier network. Welding complaints compromised approximately $27 \%$ of all complaints in the welding supply chain network with suppliers for the ten year period studied (Fig. 1). Self-caused defects are classified in the complaint category because of being manufactured in supplier. From the figure, it can be seen that it is difficult to predict accurately the volume of welding complaints relative to the total number of complaints received. Higher numbers of complaints in a certain year can be a result of changes in metal industry sales or the launch of a new product that includes more items manufactured in the supplier network. However, in Fig. 1 the launching year of the case machines in late 2008 and in 2014 correlates with an increase in welding complaints.

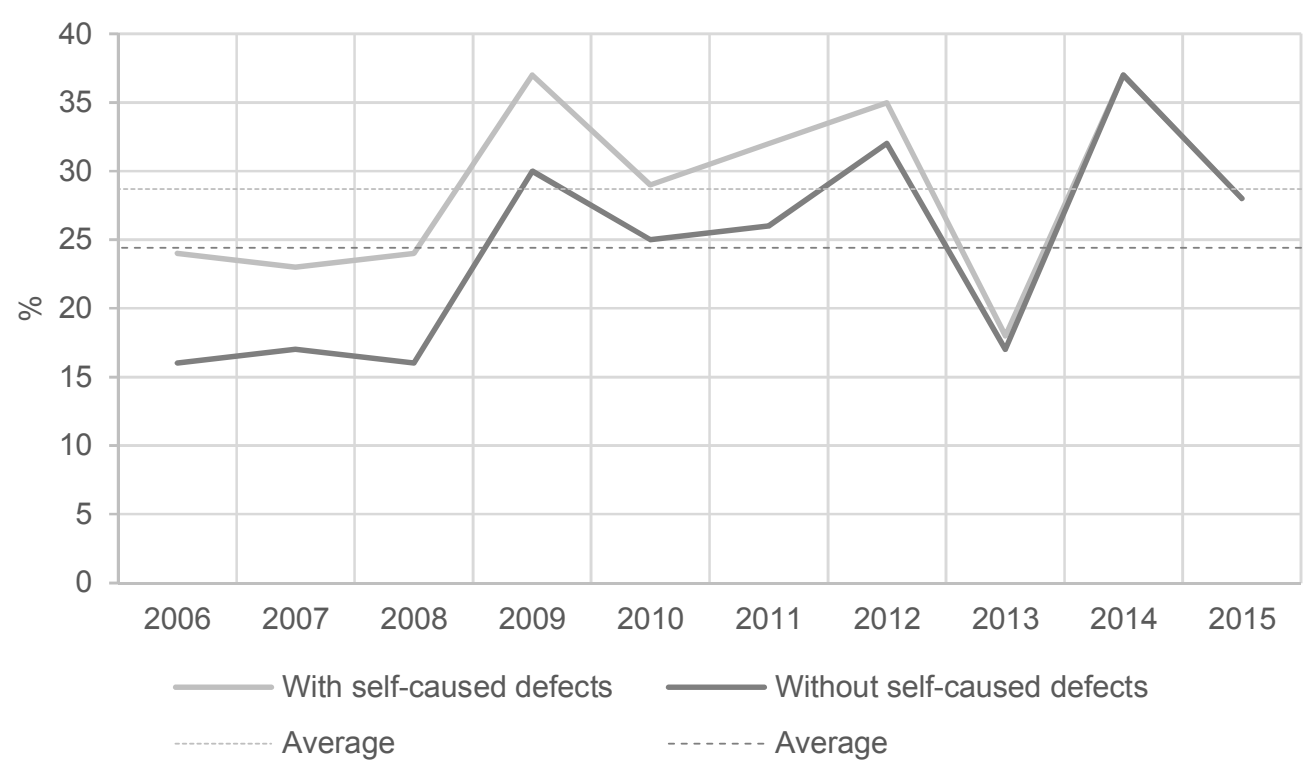

Figure 1. Welding supplier network complaints in the case supply chain network as a percentage of total complaints for the ten year period under study. 
The complaints were divided on the basis of manufacturing and welding related activities, Fig. 2. The complaint data also contain self-caused defects of the focal company which result from, for example, the assembly phase following component manufacturing by suppliers. By excluding self-caused defects of the focal company, the division of complaints is more focused on suppliers and gives better results for supplier network actions. In this particular case, important sources of complaints with actual welding were machining operations and component manufacturing. Excluding the self-caused defects, the portion of these manufacturing phases increases the most and indicates the role of self-manufacturing and testing of focal company but also the focus of actual development targets in the supplier network. The category "Other" contains product development updates, and a substantial number of complaints in the "Other" category result from internal activity, namely, thorough testing of the complete machines, which can result in damaged and broken parts. When observing the end products of the supplier network more closely, the root cause trend of complaints is close similar for all welding complaints of the particular period (Fig. 3).

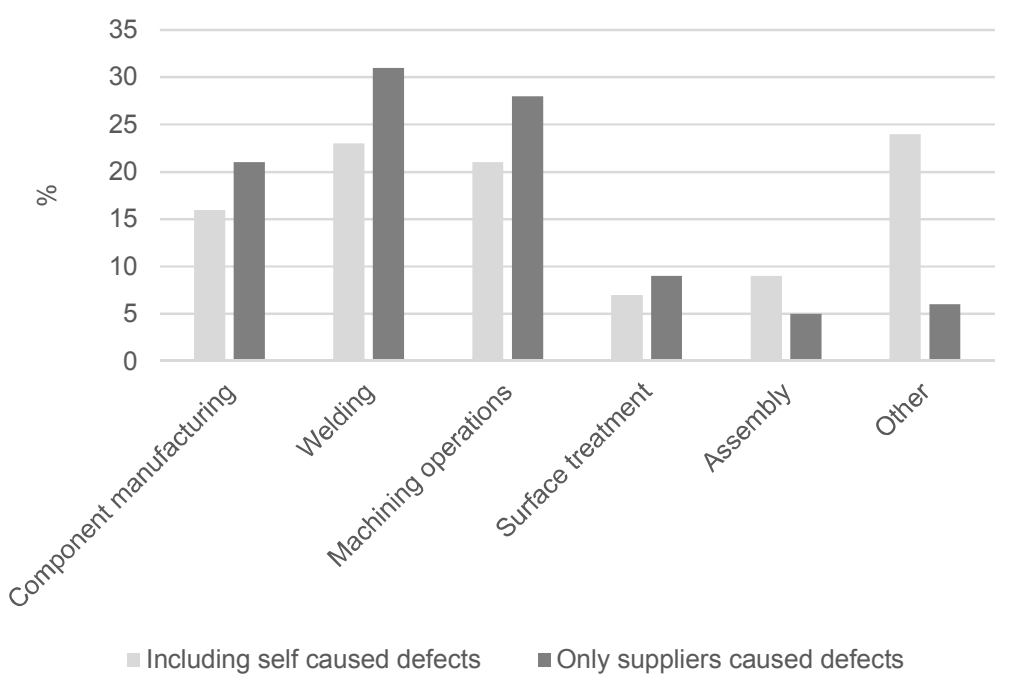

Figure 2. Complaint data division in case welding divided in categories to indicate the role of related activities in welding manufacturing.

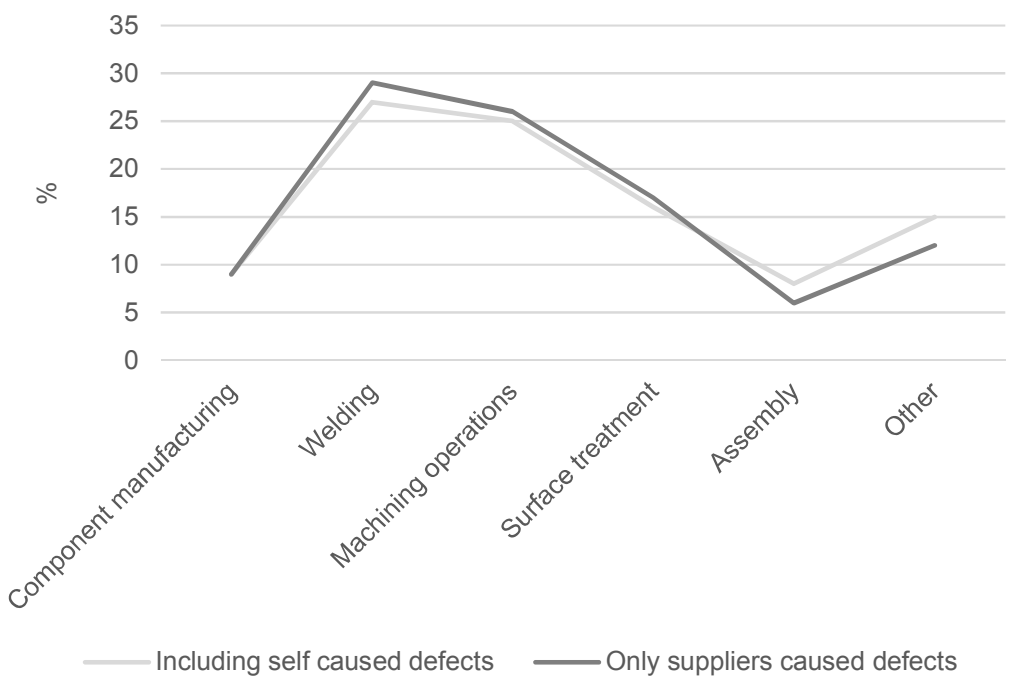

Figure 3. Complaint data categorization in a case end products follow close similar trend as overall welding complaint data of a particular production.

In Fig. 4, complaints related to the end products are shown for the number of items individually and for the total number of items in the case machine. The end products may include several of the same items and the total number of items is the result for all items. The data were collected from an item group of 3891 individual items and the total number of items was 14 907. The relative number of complaints about welding suppliers shows a small increase from the average result of $27 \%$ but also shows conformity with the sample and whole production. When excluding items which are originally manufactured in welding supplier network but are self-caused defects by the focal company, the total number of 
items manufactured in the welding supplier network decreases. This can be seen in the smaller number of complaints related to welding supplier items. Closer observation of case products in their entirety comprises the second step of the method.

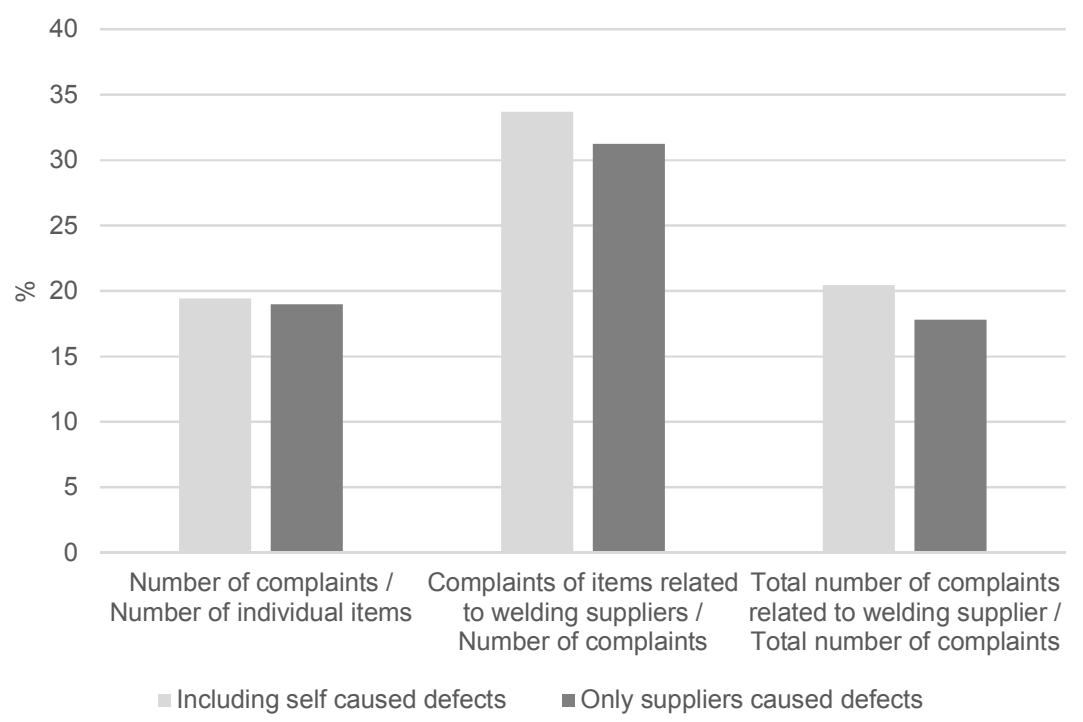

Figure 4. Share of complaints to welding supplier network in case end products. The relative number of complaints about welding suppliers (bars in the middle) is close similar result than all complaints to welding supplier network in particular production.

\subsection{Collecting Observations from Suppliers}

To decrease complaints, organizational learning and knowledge sharing are critical factors. Defects and the resultant complaints interrelate with competencies and knowledge transfer in the welding supply chain network. Result how suppliers see the potential influence to decrease the root cause of complaints indicate the targets for development of quality but also capability to fill quality demands of client.

Gathering information about the opinions of supplier network actors concerning possible development targets is the third step of the method. Welding suppliers in the supply chain network answered two survey questions: (Q1) what competence or understanding should welders, managerial employee in supplier firms and employees in the focal firm enhance to decrease the number of complaints received by the focal firm?; (Q2) how could the focal firm effect a decrease in the number of complaints through improvement of knowledge transfer? The alternatives offered as responses to Q1 followed the categorization of the complaint data: Welding operations, component manufacturing, machining operations, surface treatment and assembly of welded structures. Fig. 5 illustrates the welding supplier network view of activities related to welding in which there are prospects to decrease the number of complaints by increasing competence and information sharing and by taking actions to improve product quality.

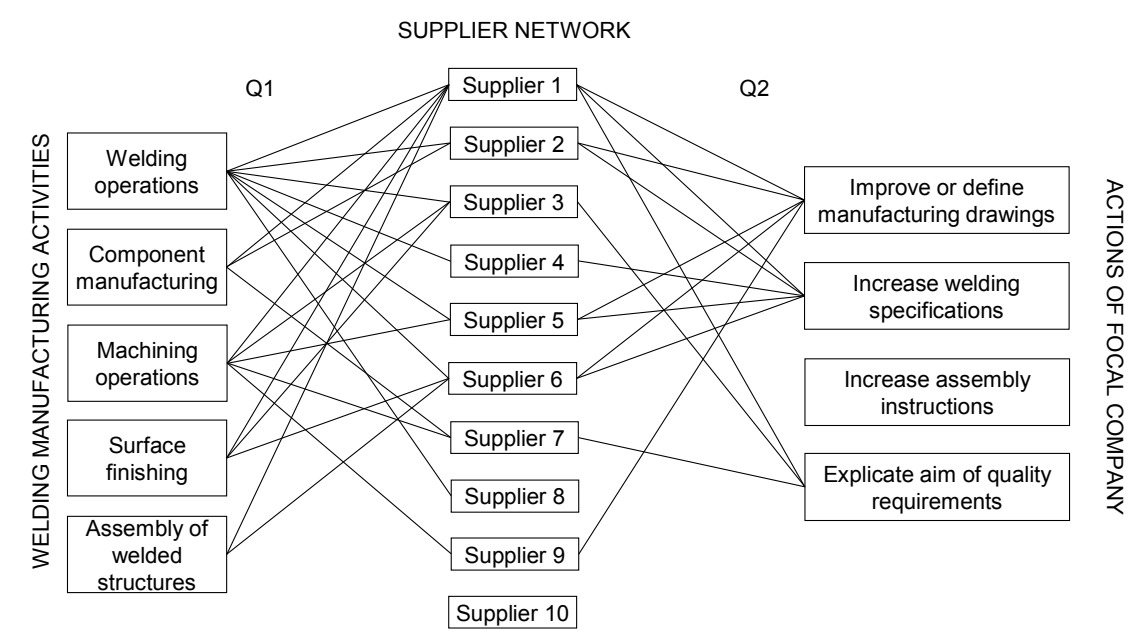

Figure 5. Results and linkages of respondents concerning questions Q1 and Q2. Ascertaining the opinions of supplier network actors is one step to find potential development targets in the case welding supply chain network. 
Responses to Q1 showed similar results to the complaints data and the survey results indicated a link between the complaints data and suppliers' view of activities needing an increase in competences. Studying the results of the survey, there is a strong connection with the categorized complaint data. Complaint data about self-caused defects and data from the survey together give a greater focus on the focal company, whereas by excluding the self-caused defects the focus turns more to the suppliers themselves and managerial employees. Excluding self-caused defects gives a better indication of the state of quality development in the supply chain network. This indicates the importance of information sharing of requirements, guidelines and instructions between the focal company and the supplier network. Investment in establishing development targets may lead to reduction in complaints and therefore greater productivity and improved profitability of welding production in the focal company and supply chain network. In responses to Q2, the improvement activities are focused on the actual welding and welding guidelines. This indicates that the focal company has potential to decrease the number of complaints by focusing on drawings and specifications.

\subsection{Integrating the Complaint Data and Suppliers' Observations}

Construction of an integrated matrix of complaints data for the ten year period and survey results of the supplier network actors is the fourth step of the method. Results of consideration of complaint data related to particular welding suppliers over the ten year period and the survey results for Q1 are presented in Table 1. 19 clearly distinguishable reasons ( $\geq 20 \%$ of complaints) can be seen as the root causes of the complaints with marked sections and 20 selections that suppliers selected for activities with potential to decrease complaints. $74 \%$ of clearly detectable reasons fully match areas in which suppliers expected increased competencies to decrease complaints and if the cases which recognized only by the supplier are analysed only $5 \%$ were a total mismatch. The results show the state of development targets at the supply chain network level.

Table 1. Integrated complaint data of particular suppliers and suppliers'observations to show development targets in the welding production case.

\begin{tabular}{|c|c|c|c|c|c|c|c|c|c|c|c|}
\hline & & $\begin{array}{l}\text { Welding } \\
\text { operations }\end{array}$ & & $\begin{array}{l}\text { Component } \\
\text { manufacturing }\end{array}$ & & $\begin{array}{l}\text { Machining } \\
\text { operations }\end{array}$ & & $\begin{array}{l}\text { Surface } \\
\text { treatment }\end{array}$ & & $\begin{array}{l}\text { Assembly of } \\
\text { welded } \\
\text { structures }\end{array}$ & \\
\hline Supplier 1 & & $2 \%$ & $\mathrm{x}$ & $49 \%$ & $\mathrm{x}$ & $40 \%$ & $\mathrm{x}$ & $4 \%$ & $\mathrm{x}$ & $0 \%$ & $\mathrm{x}$ \\
\hline Supplier 2 & & $45 \%$ & $\mathrm{x}$ & $20 \%$ & $\mathrm{x}$ & $12 \%$ & & $13 \%$ & & $2 \%$ & \\
\hline Supplier 3 & & $51 \%$ & $\mathrm{x}$ & $9 \%$ & & $18 \%$ & $\mathrm{x}$ & $5 \%$ & $\mathrm{x}$ & $11 \%$ & \\
\hline Supplier 4 & & $52 \%$ & $\mathrm{x}$ & $9 \%$ & & $31 \%$ & & $6 \%$ & & $0 \%$ & \\
\hline Supplier 5 & & $34 \%$ & $\mathrm{x}$ & $3 \%$ & & $43 \%$ & $\mathrm{x}$ & $18 \%$ & & $0 \%$ & \\
\hline Supplier 6 & & $23 \%$ & $\mathrm{x}$ & $3 \%$ & & $7 \%$ & & $38 \%$ & $\mathrm{x}$ & $21 \%$ & $\mathrm{x}$ \\
\hline Supplier 7 & & $42 \%$ & & $9 \%$ & $\mathrm{x}$ & $45 \%$ & $\mathrm{x}$ & $3 \%$ & & $0 \%$ & \\
\hline Supplier 8 & & $22 \%$ & $\mathrm{x}$ & $0 \%$ & & $68 \%$ & & $6 \%$ & & $5 \%$ & \\
\hline Supplier 9 & & $0 \%$ & & $0 \%$ & & $100 \%$ & $\mathrm{x}$ & $0 \%$ & & $0 \%$ & \\
\hline \multirow[t]{4}{*}{ Supplier 10} & & $80 \%$ & & $20 \%$ & & $0 \%$ & & $0 \%$ & & $0 \%$ & \\
\hline & $\mathrm{x}$ & \multicolumn{9}{|c|}{ Answers related to Q1. } & \\
\hline & & \multicolumn{9}{|c|}{ Q1 match with biggest impact with complaints. } & \\
\hline & & \multicolumn{9}{|c|}{ Q1 non-match with complaints. } & \\
\hline
\end{tabular}

Concretizing the tabulated combined data with case end products results the key suppliers bearing relative to production and end products. The data of the second step is used with numerical information of categorized complaints related to end products and survey results. The combined result was analysed with the RACI matrix (Table 2). The RACI matrix shows results related to the focal company and suppliers on the basis of potential developing actions and survey questions. The Q1 and Q2 results related to each supplier are shown with marked sections. R (Responsible) indicates the actual doer of the action in the manufacturing chain. In Q1 R based on complaints data of case products with majority part ( $\geq 10 \%)$ of categorized complained items in second step of method. A (Accountable) indicates financial responsibility and responsibility for the quality of the end product at the network level. C (Consulted) describes in case Q1 the 5-10 \% proportional amount of categorized complaints related to case end products in the second step of method and in Q2 C indicates the major amount of complains in the categories of manufacturing, welding and assembly. I (Informed) contains in Q1 $<5 \%$ proportional amount of those categorized complaints and in Q2 suppliers that have to be informed of changes. The matrix contains the results of Q1 and Q2 to illustrate the key targets for development actions. 
Table 2. RACI matrix of combined result of complaint data of case end products and survey results to show important suppliers for development actions in production.

\begin{tabular}{|c|c|c|c|c|c|c|c|c|c|c|c|c|c|c|c|c|c|c|}
\hline Action & & FC & S1 & S2 & $\mathbf{S 3}$ & S4 & S5 & S6 & S7 & S8 & S9 & S10 & & C & $\mathbf{M}$ & W & $\mathbf{A}$ & $\mathbf{S}$ \\
\hline Component manufacturing & & A & I & $\mathrm{R}$ & $\mathrm{R}$ & & I & $\mathrm{C} / \mathrm{I}$ & & & & I & S1 & $3.1 \%$ & $2.3 \%$ & $0.0 \%$ & $5.3 \%$ & $0.0 \%$ \\
\hline Machining operations & & A & I & $\mathrm{C} / \mathrm{I}$ & $\mathrm{R}$ & I & $\mathrm{C} / \mathrm{I}$ & I & I & I & I & & S2 & $34.4 \%$ & $9.3 \%$ & $14.1 \%$ & $15.8 \%$ & $19.6 \%$ \\
\hline Welding operations & Q1 & A & & $\mathrm{R}$ & $\mathrm{R}$ & $\mathrm{R}$ & I & $\mathrm{R}$ & I & I & & & S3 & $18.8 \%$ & $14.0 \%$ & $40.0 \%$ & $36.8 \%$ & $10.7 \%$ \\
\hline Assembly of welding structures & & A & $\mathrm{C} / \mathrm{I}$ & $\mathrm{R}$ & $\mathrm{R}$ & & & $\mathrm{R}$ & & $\mathrm{C} / \mathrm{I}$ & & & S4 & $0.0 \%$ & $3.5 \%$ & $14.1 \%$ & $0.0 \%$ & $1.8 \%$ \\
\hline Surface treatment & & A & & $\mathrm{R}$ & $\mathrm{R}$ & I & I & $\mathrm{R}$ & & & & & S5 & $3.1 \%$ & $8.1 \%$ & $1.2 \%$ & $0.0 \%$ & $1.8 \%$ \\
\hline Improve manufacturing drawings & & $\mathrm{R} / \mathrm{A}$ & I & $\mathrm{C} / \mathrm{I}$ & $\mathrm{C} / \mathrm{I}$ & I & I & $\mathrm{C} / \mathrm{I}$ & I & I & I & I & S6 & $9.4 \%$ & $3.5 \%$ & $22.4 \%$ & $10.5 \%$ & $46.4 \%$ \\
\hline Enhance welding specifications & & $\mathrm{R} / \mathrm{A}$ & I & $\mathrm{C} / \mathrm{I}$ & $\mathrm{C} / \mathrm{I}$ & $\mathrm{C} / \mathrm{I}$ & I & $\mathrm{C} / \mathrm{I}$ & I & I & I & I & S7 & $0.0 \%$ & $2.3 \%$ & $2.4 \%$ & $0.0 \%$ & $0.0 \%$ \\
\hline Enhance assembly instructions & Q2 & $\mathrm{R} / \mathrm{A}$ & I & $\mathrm{C} / \mathrm{I}$ & $\mathrm{C} / \mathrm{I}$ & I & I & $\mathrm{C} / \mathrm{I}$ & I & I & I & I & S8 & $0.0 \%$ & $2.3 \%$ & $4.7 \%$ & $5.3 \%$ & $0.0 \%$ \\
\hline Explicate aim of quality requirements & & $\mathrm{R} / \mathrm{A}$ & I & I & I & I & I & I & I & I & I & I & S9 & $0.0 \%$ & $1.2 \%$ & $0.0 \%$ & $0.0 \%$ & $0.0 \%$ \\
\hline & & & & & & & & & & & & & S10 & $3.1 \%$ & $0.0 \%$ & $0.0 \%$ & $0.0 \%$ & $0.0 \%$ \\
\hline & $\mathrm{R}$ & 4 & 0 & 4 & 5 & 1 & 0 & 3 & 0 & 0 & 0 & 0 & & & & & & \\
\hline & A & 9 & 0 & 0 & 0 & 0 & 0 & 0 & 0 & 0 & 0 & 0 & & & & & & \\
\hline Sub result & $\mathrm{C}$ & 0 & 1 & 4 & 3 & 1 & 1 & 4 & 0 & 1 & 0 & 0 & & \multicolumn{2}{|c|}{ Impact factor } & & & \\
\hline & I & 0 & 7 & 5 & 4 & 6 & 8 & 6 & 6 & 7 & 5 & 5 & & $\mathrm{R}$ & 0.3 & & & \\
\hline & & 4.8 & 0.9 & 2.5 & 2.5 & 1.1 & 1.0 & 2.3 & 0.6 & 0.9 & 0.5 & 0.5 & & A & 0.4 & & & \\
\hline & $\mathrm{R}$ & 4 & 0 & 2 & 1 & 1 & 0 & 3 & 0 & 0 & 0 & 0 & & $\mathrm{C}$ & 0.2 & & & \\
\hline & A & 9 & 0 & 0 & 0 & 0 & 0 & 0 & 0 & 0 & 0 & 0 & & I & 0.1 & & & \\
\hline \multirow[t]{3}{*}{ Summarised result } & $\mathrm{C}$ & 0 & 0 & 2 & 0 & 1 & 1 & 2 & 0 & 0 & 0 & 0 & & $\sum$ & 1.0 & & & \\
\hline & I & 0 & 5 & 2 & 1 & 1 & 4 & 2 & 2 & 1 & 2 & 0 & & & & & & \\
\hline & & 4.8 & 0.5 & 1.2 & 0.4 & 0.6 & 0.6 & 1.5 & 0.2 & 0.1 & 0.2 & 0.0 & & & & & & \\
\hline FC & & \multicolumn{17}{|c|}{ Focal company } \\
\hline $\mathrm{S} 1-\mathrm{S} 10$ & & \multicolumn{17}{|c|}{ Suppliers } \\
\hline $\mathrm{C}$ & & \multicolumn{17}{|c|}{ Component manufacturing } \\
\hline M & & \multicolumn{17}{|c|}{ Machining operations } \\
\hline W & & \multicolumn{17}{|c|}{ Welding operations } \\
\hline A & & \multicolumn{17}{|c|}{ Assembly of welded structures } \\
\hline $\mathrm{S}$ & & \multicolumn{17}{|c|}{ Surface treatment } \\
\hline
\end{tabular}

For the case example it is assumed that the impact coefficients could be set as follows: $\mathrm{R}=0.3, \mathrm{~A}=0.4, \mathrm{C}=0.2$ and $\mathrm{I}=0.1$. The values are based on logical order where responsibilities are about twice important compared to information conveying and consulting is twice important compared to sharing information. The results are based on complaints data related to particular suppliers and the impressions of the suppliers. The matrix show the key suppliers related to complaints in a particular production phase or action. The results show that the focal company is financially responsible for the end products but also the quality of manufacturing at the network level. The suppliers S2 and S6 are clearly responsible for manufacturing related complaints in the eight year period.

\section{Results}

By combining the previous stages of the study it is possible to present a stepwise method which enables perception of development targets. The study concretizes actions for production development in the supply chain network. Based on complaints, development targets are focused on the supplier network. The results give an allocated targets for development.

The structure of the developed five-step method is presented in Fig. 6. The flow chart presents the generalized stages on the left and the items on the right are corresponding methods to support the stepwise analysis. The development targets can be found from the intersection of the complaint data and the survey of the suppliers. The target pointer of the developed method is indicated by the survey results and it is parallel to customer satisfaction and describes the state of the supply chain network.

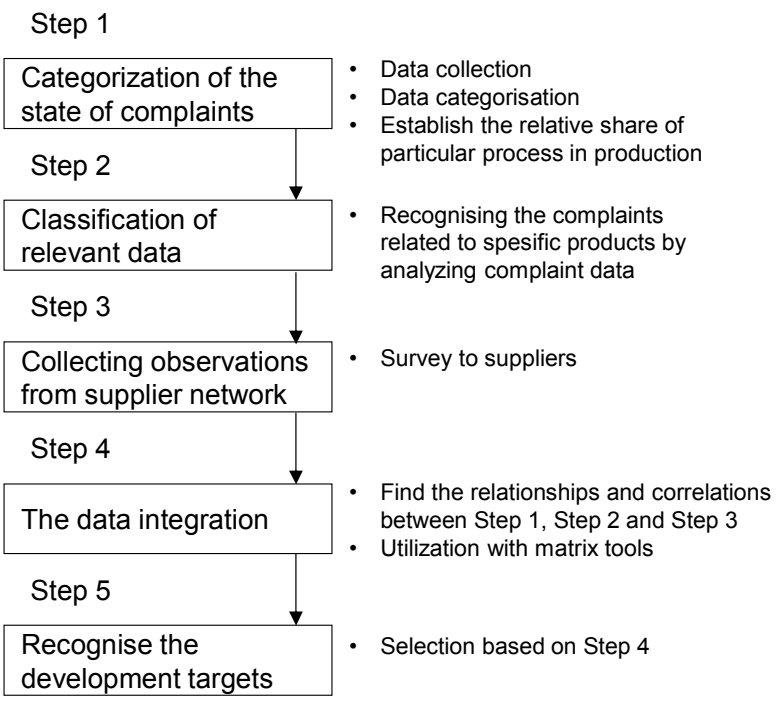

Figure 6. A five-step method to concretize actions for production process development in a supply chain network based on complaint data.

\section{Discussion}

The study presents a new method to find development targets in a supply chain network. On the basis of complaints data, a five-step approach is used to establish areas of development to improve quality and profitability in 
production. The study utilized complaints data about welding suppliers $(n=10)$ gathered over a ten year period. The results indicate that enhanced cooperation and knowledge transfer can decrease complaints and can reflect the state of particular functions in the supply chain network. A survey of supplier network members concretizes the sensed state of the supply chain network. Studied numerical data combined with survey information are at the heart of the new approach to understanding potential to increase profitability by quality assurance and control. Quantitative analysis enables databased managerial decision making and with qualitative analysis permits problem solving [59], which makes a mixed method suitable for creation of a conception of the supply chain network.

To verify the model and to show evidence to allow the five-step method to be generalized it is necessary to discuss briefly the complaints data collected in the example case. When looking at complaints related to case welding suppliers categorized by root cause of the complaint, the origin of the complaints is similar in the end products and in the information about all welding complaints regarding a particular production. This exemplifies the systematic spread of complaints for products. Welding as the actual root cause of complaints rises nearly to a third of all related activities when self-caused defects are not included in the results. Reducing the number of complaints by removing self-caused defects gives a clearer picture of the state of the supplier network. The trend lines of the root cause of the complaints to welding supplier do not critically change when all complaints are analysed or when analysis is on the basis of complaints allocated to case end products. Perceptible change is related to the overall decrease in the number of complaints concerning welding suppliers, and thus the reason for selfcaused defects can be seen in the change in the assembly category. When excluding self-caused defects, the number of complaints related to the assembly phase decreases and the portion of complaints in other categories increases. A similar trend can be noticed from small changes in the category 'other'. Such a result can be expected when a supplier network is manufacturing welded items and subassemblies for product assembly in the focal company.

A lack of communication and competencies can be reflected in complaints related to production and the results of the research give clear evidence that complaints and conscious quality assurance actions are interrelated. Complaints data divided into categories have a clear relationship with the survey of suppliers' ideas of improvement actions to decrease complaints received by the focal company. When considering only complaints that are a result of manufacturing defects by suppliers, the results direct attention more to suppliers at the managerial level. Naturally, examining complaints about items manufactured by welding suppliers but damaged by the focal company leads to greater emphasis on the focal company. The study gives better results for the state of the supplier network if self-caused defects are excluded. The results also show that the focal company may effect a decrease in the number of complaints by focusing on quality assurance through improved drawings and more accurate specifications. Such information will help suppliers in manufacturing operations to focus on particular quality demands.

The numerical data concretize the situation regarding complaints and when utilized together with the survey enable a more comprehensive picture of areas for development to be constructed than using only survey-based research. Suppliers believe that increased competencies of functions and activities related to welding can decrease complaints received by the focal company; this view is supported by the complaints data. By categorizing the survey results and quantitative complaints data in the same way, areas for development can clearly be seen. Matrix analysis of complaints data related to case end products and analysis of the survey concretized targets for developing. This approach can be useful for finding the quality development targets of products manufactured in a supplier network. Analysing the survey results by supplier and connecting this information to data of complaints of particular suppliers enables the root cause of the complaints to be concluded. This finding is supported by the $74 \%$ matching rate of the results for the survey and complaints data and the activities seen as requiring development actions. Key suppliers for development actions to decrease complaints can be recognized using the applied RACI matrix. However, unmarked sections of the RACI matrix also indicate that activities for decreasing complaints are recognized only partly by suppliers. For example among suppliers S2 and S6 the difference between the most potential developments targets based on complaints data (R) and the unrecognized ones could be even $50 \%$.

This study shows that combining production data and information about the surroundings of welding production provides a new approach to developing quality manufacturing in a welding supplier network. Based on this information, managerial and strategic decisions can be made that enhance manufacturing and marketing in the supply chain network context. The information can be expanded further to the level of each supplier and also the different areas of manufacturing and different business functions.

This study answers the research questions using the developed five-step method of integrated data and survey results of suppliers. The crucial points of production development can be recognised by combining filtered data of complaints collected from suppliers and observations formed from opinions that are gathered from the supplier network. This integration makes it possible to decrease the number of complaints and gain enhanced quality and profitability in the supply chain network context. In practise, this means that the development targets can be found at the intersection of the complaints data and survey results by using a matrix for integration of the information. The main point is to recognise feedback from a multiplicity of complaint data alongside the impressions of the actors involved. This makes it possible to handle productivity issues which are connected with welding quality assessment aspects. 
There are limitations to the research results presented in this paper. The research is trying to address supply chain network challenges by consideration of welding quality, productivity and profitability. The study considers supply chain networks in manufacturing industry and the research is illustrated with the case of welding manufacturing in a welding supplier network. Generally, companies see themselves as a centre of a network [65]. This research focus puts the focal company at the centre and surrounding associated companies view their position as a part of the focal company's network. Thus, this study is focused on particular production in a supply chain network context. It is important to know that the case example and the collected data deal only with GMAW process and therefore the content of the first step (Categorization of the state of complaints) of the method is tuned for GMAW process. The research illustrates one way to link data about supply chain network activities and formulate a way to discover the main improvements targets for manufacturing or business processes. Further research is needed to generalize the method with systematic complaint management calculations, and there is a need to assess other manufacturing and operation functions with numerical based data and observations. Furthermore, internal complaints in the focal firm must be considered when observing in more detail the cost impact on particular production methods and the end product.

\section{Conclusion}

Multiple current studies provide general information about supply chain networks from perspectives of economical, managerial and production development. This research presents a new approach to the application of collected numerical production data in efforts to improve quality in supply chain network manufacturing and reduce the number of complaints. This research uses an industrial production example of a case study of a welding supplier network. The studied numerical data about complaints related to the supplier network combined with supplier survey information provide a way to understand potential for managerial, strategic and marketing development.

This study presented a new five-step method for analysing supply chain networks on the basis of complaints related to the supplier network as a way to improve quality and increase profitability in production. In this study, the case network was studied from different perspectives using complaints related to the supplier network found in numerical production data. Using a mixed method approach gave a concrete way to visualize and understand what is going on in supply network as it appertains to product quality. Quality data concerning complaints in the supply chain network related to welding manufacturing collected over ten years (2006-2015) was capitalized on to find a new way to observe potential for enhanced quality and profitability in manufacturing. Utilization of the data, integrated with the survey results, enabled the main targets for development to be established. Based on an assumption that a lack of communication and competencies can be reflected in complaints about production, the results demonstrate the importance of knowledge transfer and competencies in quality development and show their potential to increase network behaviour and assist in meeting strategic aims.

According to the results of this research, main development targets for production can be found from the intersection of complaint data and supplier survey results by using a RACI integration matrix. Use of data-based analysis with survey results and the five-step method may help managerial decision-making and efforts by suppliers to promote manufacturing quality. The results indicate clearly the feasibility of using the new approach to determine discrepancies in supplier network activities. This study provides a concrete way, using the presented five-step method, to see and understand what is going on in a supply chain network from the perspective of welding quality assessment and total product quality. Further research into how to formulate data handling and generalize the approach will allow its considerable potential to be realized.

\section{References}

[1] M. M. Wilhelm, Managing cooperation through horizontal supply chain relations: Linking dyadic and network levels of analysis, Journal of Operations Management, Vol. 29 (7-8), pp. 663-676, 2011. doi: 10.1016/j.jom.2011.03.003.

[2] C. Ramos, S. C. Henneberg, P. Naudé, Understanding network picture complexity: An empirical analysis of contextual factors, Industrial Marketing Management, Vol. 41 (6), pp. 951-972, 2012. doi: 10.1016/j.indmarman.2011.12.001.

[3] Z. Liu, J. M. Cruz, Supply chain networks with corporate financial risks and trade credits under economic uncertainty, International Journal of Production Economics, Vol. 137 (1), pp. 55-67, 2012. doi: 10.1016/j.ijpe.2012.01.012.

[4] T. Ritter, I. F. Wilkinson, W. J. Johnston, Managing in complex business networks, Industrial Marketing Management, Vol. 33 (3), pp. 175-183, 2004. doi: 10.1016/j.indmarman.2003.10.016.

[5] J. Barnes, Y. Liao, The effect of individual, network, and collaborative competencies on the supply chain management system, International Journal of Production Economics, Vol. 140, pp. 888-899, 2012. doi: 10.1016/j.ijpe.2012.07.010.

[6] L. Knight, Network learning: Exploring learning by interorganizational networks, Human relations, Vol. 55 (4), pp. 427-454, 2002. doi: 10.1177/0018726702554003.

[7] L-E. Gadde, L. Huemer, H. Håkansson, Strategizing in industrial networks, Industrial Marketing Management, Vol. 32 (5), pp. 357-364, 2003. doi: 10.1016/S0019-8501(03)00009-9.

[8] D. Ford, L-E. Gadde, H. Håkansson, I. Snehota, Managing Networks. In 18th IMP Conf., Perth, Australia, December 2002, pp. 11-13.

[9] S. Mouzas, S. Henneberg, P. Naudé, Developing network insight, Industrial Marketing Management, Vol. 37 (2), pp. 167-180, 2008. doi: 10.1016/j.indmarman.2007.01.003. 
[10] M. H. Abrahamsen, S. C. Henneberg, P. Naudé, Using actors' perceptions of network roles and positions to understand network dynamics, Industrial Marketing Management, Vol. 41 (2), pp. 259-269, 2012. doi: 10.1016/j.indmarman.2012.01.008.

[11] D. Ford, M. Redwood, Making sense of network dynamics through network pictures: A longitudinal case study, Industrial Marketing Management, Vol. 34 (7), pp. 648-657, 2005. doi: 10.1016/j.indmarman.2005.05.008.

[12] S. Leek, K. Mason, Network pictures: Building an holistic representation of a dyadic business-to-business relationship, Industrial Marketing Management, Vol. 38 (6), pp. 599-607, 2009. doi: 10.1016/j.indmarman.2009.05.013.

[13] S. C. Henneberg, S. Mouzas, P. Naudé, Network pictures: concepts and representations, European Journal of Marketing, Vol. 40 (3-4), pp. 408-429, 2006. doi: $10.1108 / 03090560610648129$.

[14] S. Leek, K. Mason, The utilisation of network pictures to examine a company's employees' perceptions of a supplier relationship, Industrial Marketing Management, Vol. 39 (3), pp. 400-412, 2010. doi: 10.1016/j.indmarman.2007.08.010.

[15] E. Holmen, T. B. Aune, A-C. Pedersen, Network pictures for managing key supplier relationships, Industrial Marketing Management, Vol. 42 (2), pp. 139-151, 2013. doi: 10.1016/j.indmarman.2012.12.003.

[16] C. Roseira, C. Brito, D. Ford, Network pictures and supplier management: An empirical study, Industrial Marketing Management, Vol. 42 (2), pp. 234-247, 2013. doi: 10.1016/j.indmarman.2012.08.006.

[17] I. Colville, A. Pye, A sensemaking perspective on network pictures, Industrial Marketing Management, Vol. 39 (3), pp. 372-380, 2010. doi: 10.1016/j.indmarman.2009.03.012.

[18] S. Wang, T. Wu, S-J. Weng, J. Fowler, A control chart based approach to monitoring supply network dynamics using Kalman filtering, International Journal of Production Research, Vol. 50 (11), pp. 3137-3151, 2012. doi: 10.1080/00207543.2011.597788.

[19] M. Rudberg, J. Olhager, Manufacturing net-works and supply chains: an operation strategy perspective, The International Journal of Management Science, Vol. Omega 31, pp. 29-39, 2003. doi: 10.1016/S0305-0483(02)00063-4.

[20] C-W. Chang, D. M. Chiang, F-Y. Pai, Cooperative strategy in supply chain networks, Industrial Marketing Management, Vol. 41, pp. 1114-1124, 2012. doi: 10.1016/j.indmarman.2012.04.011.

[21] S. A. Dellana, J. F. Kros, An exploration of quality management practices, perceptions and program maturity in the supply chain, International Journal of Operations \& Production Management, Vol. 34 (6), pp. 786-806, 2014. doi: 10.1108/IJOPM-03-2013-0105.

[22] L. Bizzi, A. Langley, Studying processes in and around networks, Industrial Marketing Management, Vol. 41, pp. 224234, 2012. doi: 10.1016/j.indmarman.2012.01.007.

[23] H. Seok, K. Kim, S. Y. Nof, Intelligent contingent multisourcing model for resilient supply networks, Expert Systems with Applications, Vol. 51 (1), pp. 107-119, 2016. doi: 10.1016/j.eswa.2015.12.026.
[24] R. Lamming, T. Johnsen, J. Zheng, C. Harland, An initial classification of supply networks, International Journal of Operations \& Production Management, Vol. 20 (6), pp. 675691, 2000. doi: 10.1108/01443570010321667.

[25] Z. Chen, C. Teng, D. Zhang, J. Sun, Modelling inter-supply chain competition with resource limitation and demand disruption, International Journal of Systems Science, Vol. 47 (79, pp. 1644-1658, 2016. doi: 10.1080/00207721.2014.942499.

[26] J. F. Dyer, N. W. Hatch, Relation-specific capabilities and barriers to knowledge transfers: creating advantage through network relationships, Strategic Management Journal, Vol. 27 (8), pp. 701-719, 2006. doi: 10.1002/smj.543.

[27] J. F. Dyer, K. Nobeoka, Creating and managing a high performance knowledge-Sharing network: The Toyota Case, Strategic Management Journal, Vol. 21 (3), pp. 345-367, 2000. doi: $\quad 10.1002 /(\mathrm{SICI}) 1097-0266(200003) 21: 3<345:: A I D-$ SMJ96 >3.0.CO;2-N.

[28] M. Cao, M. A. Vonderembse, Q. Zhang, T. S. Ragu-Nathan, Supply chain collaboration: conceptualisation and instrument development, International Journal of Production Research, Vol. 48 (22), pp. 6613-6635, 2010. doi: $10.1080 / 00207540903349039$.

[29] G. Xie, W. Yue, S. Wang, K. K. Lai, Quality investment and price decision in a risk-averse supply chain, European Journal of Operational Research, Vol. 214, pp. 403-410, 2011. doi: 10.1016/j.ejor.2011.04.036.

[30] U. Reisgen, M. Beckers, G. Buchholz, K. Willms, Progress Towards Model Based Optimisation Of Gas Metal Arc Welding Processes, Welding in the World, Vol. 56 (9), pp. 3540, 2012.

[31] D. N. Shackleton, Reducing failure risk in welded components, Welding in the World, Vol. 50 (9-10), pp. 92-97, 2006.

[32] N. Katz, D. Lazer, H. Arrow, N. Contractor, Network Theory of Small Groups, Small Group Research, Vol. 35 (3), pp. 307 332, 2004.

[33] R. Sebastiani, D. Corsaro, F. Montagnini, A. Tzannis, Marketing in Trasition: Scarcity, Globalism, \& Sustainability, Proc. Academy of Marketing Science, pp. 8-12, 2009.

[34] D. Ford, L-E. Gadde, H. Håkansson, A. Lundgren, I. Snehota, P. Turnbull, D. Wilson, Managing Business Relationships (John Wiley \& Sons, 1998).

[35] S. Ö. Ekici, Ö. Kabak, F. Ûlening, Linking to compete: Logistics and global competitiveness interaction, Transport Policy, Vol. 48, pp. 117-128, 2016. doi: 10.1016/j.tranpol.2016.01.015.

[36] A. Awheda, M. Nizam, A. Rahman, R. Ramli, H. Arshad, Factors related to supply chain network members in SMEs, Journal of Manufacturing Technology Management, Vol. 27 (2), pp. 312-335, 2016. doi: 10.1108/JMTM-01-2015-0005.

[37] T. Paksoy, E. Özceylan, G-W. Weber, Profit oriented supply chain network optimization, Central European Journal of Operation Research, Vol. 21, pp. 455-478, 2013. doi: 10.1007/s10100-012-0240-0.

[38] F. Pan, R. Nagi, Multi-echelon supply chain network design in agile manufacturing, The International Journal of Management Science, Vol. Omega 41, pp. 969-983, 2013. doi: 10.1016/j.omega.2012.12.004. 
[39] H. Håkansson, D. Ford, How should companies interact in business networks, Journal of Business Research, Vol. 55 (2), pp. 133-139, 2002. doi: 10.1016/S0148-2963(00)00148-X.

[40] M. Barrat, R. Barrat, Exploring internal and external supply chain linkages: Evidence from the field, Journal of Operations Management, Vol. 29, pp. 514-528, 2011. doi 10.1016/j.jom.2010.11.006.

[41] A. Giroud, J. Scott-Kennel, MNE linkages in international business: A framework for analysis, International Business Review, Vol. 18 (6), pp. 555-566, 2009. doi: 10.1016/j.ibusrev.2009.07.004.

[42] K. Mason, S. Leek, Learning to Build a Supply Network: An Exploration of Dynamic Business Models, Journal of Management Studies, Vol. 45 (4), pp. 774-799, 2008. doi: 10.1111/j.1467-6486.2008.00769.x.

[43] J-S. Chen, R. V. Mahto, A. S. Lovvorn, A Conceptual Framework on Knowledge Transfer within Multinational Corporations: A Strategic Orientation, International Journal of Management, Vol. 30 (4), pp. 322-339, 2013.

[44] M. Mulder, Competentieontwikkeling in organisaties. Perspectieven en praktijk (Elsevier, 2001).

[45] G. Liu, S. P. Sethi, J. Zhang, Myopic vs. far-sighted behaviours in a revenue-sharing supply chain with reference quality effects, International Journal of Production Research, 2015. doi: $10.1080 / 00207543.2015 .1068962$.

[46] G. Copani, M. Urgo, Innovative flexibility-oriented business models and system configuration approaches: An industrial application, CIRP Journal of Manufacturing Science and Technology, Vol. 11, pp. 10-17, 2015. doi: 10.1016/j.cirpj.2015.05.008.

[47] A. B. Steven, Y. Dong, T. Corsi, Global sourcing and quality recalls: An empirical study of outsourcing-supplier concentration-product recalls linkages, Journal of Operations Management, Vol. 32 (5), pp. 241-253, 2014. doi: 10.1016/j.jom.2014.04.003.

[48] R. Xiao, Z. Cai, X. Zhang, A Production Optimization Model of Supply-driven Chain with Quality Uncertainty, Journal of Systems Science and Systems Engineering, Vol. 21 (2), pp. 144-160, 2012. doi: 10.1007/s11518-011-5184-8.

[49] J. Toivanen, H. Eskelinen, P. Kah, J. Martikainen, Connection Between the Number of Complaints About Welding Suppliers and End Product Quality: The Case of Customized Welding Production, International Journal of Mechanical Engineering and Applications, Vol. 4 (2), pp. 43-49, 2016. doi: 10.11648/j.ijmea.20160402.12.

[50] T. Gruber, S. C. Henneberg, B. Ashnai, P. Naudé, Complaint resolution management expectations in an asymmetric business-to-business context, Journal of Business \& Industrial Marketing, Vol. 25 (5), pp. 360-371, 2010. doi:10.1108/08858621011058124.
[51] M. M. Ahmad, N. Dhafr, Establishing and improving manufacturing performance measures, Robotics and Computer Integrated Manufacturing, Vol. 18 (3-4) pp. 171-176, 2002. doi: 10.1016/S0736-5845(02)00007-8.

[52] X. Tang, H. Yun, Data model for quality in product lifecycle, Computers in industry, Vol. 59 (2-3) pp. 167-179, 2008. doi: 10.1016/j.compind.2007.06.011.

[53] M. A. Bellamy, R. C. Basole, Network Analysis of Supply Chain Systems: A Systematic Review and Future Research, Systems Engineering, Vol. 16 (2), pp. 235-249, 2013. doi: $10.1002 /$ sys. 21238 .

[54] Y. Kim, T. Y. Choi, T. Yan, K. Dooley, Structural investigation of supply networks: A social network analysis approach, Journal of Operations Management, Vol. 29 (3), pp. 194-211, 2011. doi: doi:10.1016/j.jom.2010.11.001.

[55] R. K. Yin, Case Study Research: Designs and Methods (Sage Publication, 1994).

[56] A. Halinen, J- $\AA$. Törnroos, Using case methods in the study of contemporary business networks, Journal of Business Research, Vol. 58 (9), pp. 1285-1297, 2005. doi: 10.1016/j.jbusres.2004.02.001.

[57] G. Guest, E. E. Namey, M. L. Mitchell, Collecting Qualitative Data: A Field Manual for Applied Research (Sage Publications Inc., 2013).

[58] R. E. Kass, U. T. Eden, E. N. Brown, Analysis of Neural Data (2nd edition, Springer, 2014).

[59] B. Render, R. M. Stair Jr., M. E. Hanna, Quantitative Analysis for Management (8th edition, Prentice Hall, 2003).

[60] M. B. Miles, A. M. Huberman, Qualitative Data Analysis: An Expanded Sourcebook (2nd edition, Sage Publications Inc., 1994).

[61] R. Mcadam, S. Mcintyre, A business process improvement methodology which incorporates learning organization concepts, Total Quality Management, Vol. 8 (2-3), pp. 221225, 1997. doi: 10.1080/09544129710071.

[62] P. Ravesteyn, S. Jansen, AMCIS 2009 Proceedings, Proc. AMCIS, San Francisco, 2009, Paper 632.

[63] C. Cabanillas, M. Resinas, A. Ruiz-Cortés, Automated Resource Assignment in BPMN Models Using RACI Matrices, In R. Meersman et al. (Ed.), OTM 2012 (Springer, 2012, 56-73). doi: 10.1007/978-3-642-33606-5_5.

[64] J. Toivanen, J. Martikainen, P. Heilmann, From supply chain to welding network: A framework of the prospects of networks in welding, Mechanika, Vol. 21 (2), pp. 154-160, 2015. doi: 10.5755/j01.mech.21.2.8463.

[65] C. Ramos, Developing Network Pictures as a Research Tool: Capturing the Output of Individuals' Sense-making in Organisational Networks, Ph.D. dissertation, University of Bath, 2008. 